\title{
Aquatic bird disease and mortality as an indicator of changing ecosystem health
}

\author{
Scott H. Newman ${ }^{1,2,4,5, *}$, Aleksei Chmura ${ }^{2}$, Kathy Converse ${ }^{3}$, A. Marm Kilpatrick ${ }^{2}$, \\ Nikkita Patel ${ }^{2}$, Emily Lammers ${ }^{1}$, Peter Daszak ${ }^{2}$ \\ ${ }^{1}$ Wildlife Trust, 460 West 34th Street, New York, New York 10001, USA \\ ${ }^{2}$ Consortium for Conservation Medicine, 460 West 34th Street, New York, New York 10001, USA \\ ${ }^{3}$ USGS National Wildlife Health Center, 6006 Schroeder Road, Madison, Wisconsin 53711, USA
}

${ }^{4}$ Present address: Food and Agriculture Organization of the United Nations (FAO), Infectious Disease Group, Emergency Centre for Transboundary Animal Diseases (ECTAD), Animal Health Service, Viale delle Terme di Caracalla, Rome 00100, Italy

${ }^{5}$ Present address: Wildlife Conservation Society, Field Veterinary Program, 2300 Southern Boulevard, Bronx, New York 10460, USA

\begin{abstract}
We analyzed data from pathologic investigations in the United States, collected by the USGS National Wildlife Health Center between 1971 and 2005, into aquatic bird mortality events. A total of 3619 mortality events was documented for aquatic birds, involving at least 633708 dead birds from 158 species belonging to 23 families. Environmental causes accounted for the largest proportion of mortality events (1737 or $48 \%$ ) and dead birds (437 258 or $69 \%$ ); these numbers increased between 1971 and 2000, with biotoxin mortalities due to botulinum intoxication (Types C and E) being the leading cause of death. Infectious diseases were the second leading cause of mortality events $(20 \%)$ and dead birds (20\%), with both viral diseases, including duck plague (Herpes virus), paramyxovirus of cormorants (Paramyxovirus PMV1) and West Nile virus (Flavivirus), and bacterial diseases, including avian cholera (Pasteurella multocida), chlamydiosis (Chalmydia psittici), and salmonellosis (Salmonella sp.), contributing. Pelagic, coastal marine birds and species that use marine and freshwater habitats were impacted most frequently by environmental causes of death, with biotoxin exposure, primarily botulinum toxin, resulting in mortalities of both coastal and freshwater species. Pelagic birds were impacted most severely by emaciation and starvation, which may reflect increased anthropogenic pressure on the marine habitat from over-fishing, pollution, and other factors. Our study provides important information on broad trends in aquatic bird mortality and highlights how long-term wildlife disease studies can be used to identify anthropogenic threats to wildlife conservation and ecosystem health. In particular, mortality data for the past $30 \mathrm{yr}$ suggest that biotoxins, viral, and bacterial diseases could have impacted $>5$ million aquatic birds.
\end{abstract}

KEY WORDS: Emerging infectious diseases $\cdot$ Aquatic birds $\cdot$ Seabirds $\cdot$ Ecosystem $\cdot$ Health $\cdot$ Bird mortality · Sentinel species · Conservation medicine - Botulism · Viral disease · Bacterial disease

\section{INTRODUCTION}

Increasingly, wildlife biologists, veterinarians, and ecologists are reporting significant wildlife mortality events (Dobson \& Foufopoulos 2001, Friend et al. 2001); many of these are later determined to be caused by infectious diseases or acute or chronic pollution. In some cases, diseases have caused population declines and have threatened species diversity (Warner 1968, Lyles
\& Dobson 1993, Berger et al. 1998, Daszak \& Cunningham 1999). Diseases that have recently increased in incidence or impact, or have recently moved into a new host population or geographic region are termed 'emerging diseases', following the terminology adopted widely for a number of human diseases (Lederberg et al. 1992, Smolinski et al. 2003). Like emerging diseases of humans, emerging diseases of wildlife are often directly linked to anthropogenic environmental changes 
that provide the driving force behind their recent change in incidence, impact, geography, or host (Schrag \& Wiener 1995, Daszak et al. 2001).

Despite the recognition of emerging diseases as a potentially key threat to wildlife populations, research on the links among anthropogenic activities, on changes in ecological health, and on disease emergence has largely concentrated on terrestrial ecosystems, with a few notable exceptions. Marine diseases serve as indicators of global climate change (Harvell et al. 2002), and marine species of high conservation concern are affected by increasingly wellstudied emerging diseases (Harvell et al. 1999), such as morbilliviruses in dolphins (Domingo et al. 1990), canine distemper viruses in seals (Stone 2000), and fibropapillomas in sea turtles (Williams et al. 1994). For aquatic birds, there has been a great deal of interest in the effects of acute and chronic pollution (petroleum, pesticides, heavy metals, or other industrial byproducts), collisions with man-made structures (buildings, power lines, or wind turbines), refuse ingestion, fishing line or net entanglement, and changes in food availability and climate on their populations (Sydeman et al. 1994, Camphuysen \& Heubeck 2001, Carter 2003, Newman et al. 2003, 2006, Burger \& Gochfeld 2004). However, there have been few large-scale studies of trends in infectious and non-infectious diseases in this fauna (Friend et al. 2001, Muzzafar \& Jones 2004).

In order to better understand the disease, environmental, and anthropogenic threats that pose the greatest dangers to aquatic bird populations, we have analyzed 30 yr of diagnostic evaluations from dead aquatic birds (seabirds, shorebirds, waders, and sea ducks) recovered in the US or US territories and diagnosed by wildlife pathologists from the US Geological Service, National Wildlife Health Center (NWHC). Our analyses provide a review of the magnitude as well as the temporal and spatial patterns of diseases and suggest several anthropogenic drivers of these diseases in aquatic birds.

\section{MATERIALS AND METHODS}

We selected aquatic bird (seabirds, shorebirds, waders, and sea ducks) mortality data in the US and US territories from 2 databases ('Diagnostic Database' and 'Epizoo') maintained by the NWHC since 1971. The Diagnostic Database contains information from necropsies on individual birds conducted at the NWHC when no mass mortality was reported. The Epizoo database contains information about mortality events observed in the field and reported by biologists, researchers, diagnostic laboratories, or the general pub- lic. In most cases, carcasses were sent to the NWHC for necropsy. Field necropsy data and diagnoses are entered into this database when biologists or field veterinarians have followed the appropriate necropsy and sample collection guidelines and diagnostic results from the appropriate diagnostic laboratories have been provided. For all mass mortality events, information provided to the NWHC included: (1) a gross necropsy report, (2) a complete set of formalin-fixed tissues for histology, and (3) additional refrigerated and frozen tissues for toxicology and infectious disease testing. For all cases used in the present study, a final diagnosis was determined by a NWHC pathologist.

Each event in the Diagnostic Database or Epizoo used in the present study was described by the following information: record identification number, date of collection, date on which the event started and ended (if applicable), eco-region, flyway, county and state of collection, name of refuge or park (if applicable), contact persons, species name, common name, recent or anticipated population changes, number of sick individuals by species, clinical signs, number of dead individuals by species, estimated number of dead individuals, estimated population, environmental conditions, habitat changes, recent weather changes, history of disease events at this site, and final diagnosis. The general cause of mortality for individuals or in events was further refined into the categories noted in Table 1.

Note that we considered botulism an environmental cause of death rather than a lethal infectious disease because the majority of avian mortality due to this disease is actually caused by ingestion of the toxin, rather than primary infection of the gastrointestinal tract by Clostridium botulinum bacteria (Rocke \& Friend 1999). We have discussed the implications of this categorization in the discussion. A diagnosis of 'pathology' was used if there was evidence of histological changes observed by microscopy that was suggestive of insult such as a disease or toxin exposure. However, because no toxin or disease could be identified as having contributed to the observed histological lesion, these birds were grouped independently from other causes of mortality. A diagnosis of 'emaciation/starvation' was made if birds were physically emaciated, no gross or microscopic lesions or injuries were identified during necropsy, and no other causes of mortality could be determined (diseases, toxins, biotoxins, etc.). An 'undetermined' diagnosis was given to any case in which no cause of mortality could be determined.

For the purposes of the present study, we included only species that inhabit oceans for $>8$ mo of the year and did not include freshwater-inhabiting 'waterfowl' species. Based on their habitat use and natural history, species were divided into groups for additional analyses: (1) pelagic/offshore species that use primarily 
Table 1. General causes of aquatic bird mortality events (number and percentage) for each of the 23 bird families, according to data from 2 USGS databases, Epizoo and Diagnostic. Specific causes of mortality were grouped into 6 categories of mortality events anthropogenic: fishing net entrapment, gunshot, powerline collision, and trauma (vehicle, collisions, or unknown source); environmental: biotoxin, weather, natural biology-depredated or intra- or con-specific trauma, emaciation/starvation; infectious: bacterial, viral, parasitic, fungal, undiagnosed bacterial or viral; pathology with no etiology: undiagnosed, but histological lesions in tissue samples; toxicosis: heavy metal, nutritional (selenium or salt), oil (petroleum and non-petroleum), pesticide (carbamate, organophosphate, organochlorine), poison (cyanide, calcium nitrate, strychinine), undetermined poison; undetermined: no diagnosis

\begin{tabular}{|c|c|c|c|c|c|c|c|c|c|c|c|c|c|}
\hline \multirow[t]{3}{*}{ Family } & \multicolumn{12}{|c|}{ Number and percentage of mortality events per family } & \multirow{3}{*}{$\begin{array}{c}\text { Total } \\
\text { numbers } \\
\text { (n) }\end{array}$} \\
\hline & \multicolumn{2}{|c|}{$\begin{array}{l}\text { Anthropo- } \\
\text { genic }\end{array}$} & \multicolumn{2}{|c|}{$\begin{array}{l}\text { Environ- } \\
\text { mental }\end{array}$} & \multicolumn{2}{|c|}{ Infectious } & \multicolumn{2}{|c|}{$\begin{array}{c}\text { Pathology with } \\
\text { no etiology }\end{array}$} & \multicolumn{2}{|c|}{ Toxicosis } & \multicolumn{2}{|c|}{ Undetermined } & \\
\hline & & & (n) & $(\%)$ & (n) & $(\%)$ & (n) & $(\%)$ & (n) & $(\%)$ & (n) & $(\%)$ & \\
\hline Anatidae & 9 & 4 & 62 & 26 & 105 & 45 & 13 & 6 & 25 & 11 & 21 & 9 & 235 \\
\hline Gaviidae & 16 & 12 & 34 & 25 & 22 & 16 & 29 & 21 & 22 & 16 & 15 & 11 & 138 \\
\hline Diomedeidae & 2 & 10 & 1 & 5 & 1 & 5 & 13 & 65 & 1 & 5 & 2 & 10 & 20 \\
\hline Procellariidae & 15 & 21 & 14 & 20 & 2 & 3 & 29 & 41 & 5 & 7 & 5 & 7 & 70 \\
\hline Hydrobatidae & 1 & 20 & 3 & 60 & 0 & 0 & 0 & 0 & 1 & 20 & 0 & 0 & 5 \\
\hline Phaethontidae & 0 & 0 & 0 & 0 & 0 & 0 & 3 & 100 & 0 & 0 & 0 & 0 & 3 \\
\hline Sulidae & 3 & 8 & 13 & 33 & 12 & 31 & 6 & 15 & 1 & 3 & 4 & 10 & 39 \\
\hline Pelecanidae & 24 & 7 & 169 & 47 & 64 & 18 & 27 & 8 & 19 & 5 & 53 & 15 & 356 \\
\hline Phalacrocoracidae & 15 & 6 & 87 & 35 & 88 & 35 & 30 & 12 & 6 & 2 & 26 & 10 & 252 \\
\hline Anhingidae & 0 & 0 & 0 & 0 & 0 & 0 & 0 & 0 & 1 & 100 & 0 & 0 & 1 \\
\hline Fregatidae & 1 & 33 & 0 & 0 & 0 & 0 & 0 & 0 & 0 & 0 & 2 & 67 & 3 \\
\hline Ardeidae & 24 & 5 & 228 & 45 & 98 & 19 & 67 & 13 & 45 & 9 & 45 & 9 & 507 \\
\hline Threskiornithidae & 3 & 4 & 53 & 73 & 5 & 7 & 6 & 8 & 4 & 5 & 2 & 3 & 73 \\
\hline Ciconiidae & 2 & 67 & 0 & 0 & 0 & 0 & 0 & 0 & 1 & 33 & 0 & 0 & 3 \\
\hline Phoenicopteridae & 0 & 0 & 1 & 50 & 0 & 0 & 0 & 0 & 1 & 50 & 0 & 0 & 2 \\
\hline Charadriidae & 20 & 10 & 83 & 43 & 27 & 14 & 51 & 26 & 6 & 3 & 7 & 4 & $19 \overline{4}$ \\
\hline Haematopodidae & 0 & 0 & 0 & 0 & 1 & 100 & 0 & 0 & 0 & 0 & 0 & 0 & 1 \\
\hline Recurvirostridae & 2 & 2 & 80 & 75 & 15 & 14 & 3 & 3 & 1 & 1 & 5 & 5 & 106 \\
\hline Scolopacidae & 5 & 1 & 435 & 80 & 38 & 7 & 15 & 3 & 23 & 4 & 31 & 6 & 547 \\
\hline Laridae & 36 & 4 & 450 & 45 & 233 & 23 & 83 & 8 & 86 & 9 & 114 & 11 & 1002 \\
\hline Stercorariidae & 0 & 0 & 1 & 33 & 0 & 0 & 0 & 0 & 1 & 33 & 1 & 33 & 3 \\
\hline Alcidae & 2 & 3 & 26 & 45 & 3 & 5 & 8 & 14 & 9 & 16 & 10 & 17 & 58 \\
\hline Cinclidae & 0 & 0 & 0 & 0 & 0 & 0 & 1 & 100 & 0 & 0 & 0 & 0 & 1 \\
\hline Total & & & & & & & & & & & & & 3619 \\
\hline
\end{tabular}

pelagic habitats, (2) near-shore/coastal species that spend most of their time within several $\mathrm{km}$ of the coastline, and (3) freshwater species that use both marine and freshwater habitats. We cross-referenced each individual from the Diagnostic Database to rule out dual reporting in the Epizoo database. We used MATLAB (MathWorks) to perform descriptive statistics and to create charts and graphs. Analyses were also performed to examine basic geographic patterns of seabird mortality by mapping mortality incident locations in ESRIArcMap9.0 Geographic Information System (ESRI). Because there are different numbers of inland and shoreline states, we examined the percentage of each general category that contributed to the mortality events in inland and shoreline states.

\section{RESULTS}

\section{Causes of mortality}

Between 1971 and 2005, 3619 mortality events were reported in aquatic birds, for which 1 or more birds were examined by wildlife pathologists to diagnose the cause of mortality. Of the mortality events (involving multiple birds at a single location; Fig. 1a) or individual bird deaths (Fig. 1b), California reported the largest number of mortality events, while California and Nevada reported the largest number of dead aquatic birds. The 3619 mortality events involved 633708 dead birds from 158 species belonging to 23 families: Alcidae, Anhingidae, Anatidae, Ardeidae, Charadriidae, Ciconiidae, Cinclidae, Diomedeidae, Fregatidae, Gaviidae, Haematopodidae, Hydrobatidae, Laridae, Pelecanidae, Phaethontidae, Phalacrocoracidae, Phoenicopteridae, Procellariidae, Recurvirostridae, Scolopacidae, Stercorariidae, Sulidae, and Threskiornithidae (Supplementary Material available at www.int-res.com/articles/suppl/m352p299_app.xls, Table 1). The frequency and causes of mortality events by family are reported here in Table 1 . The causes of mortality events and the total number of dead birds based on habitat are reported in Table 2. The largest number of mortality events was observed in Laridae, Scolopacidae, and Ardeidae, and was found in the nearshore/coastal habitat use category. 

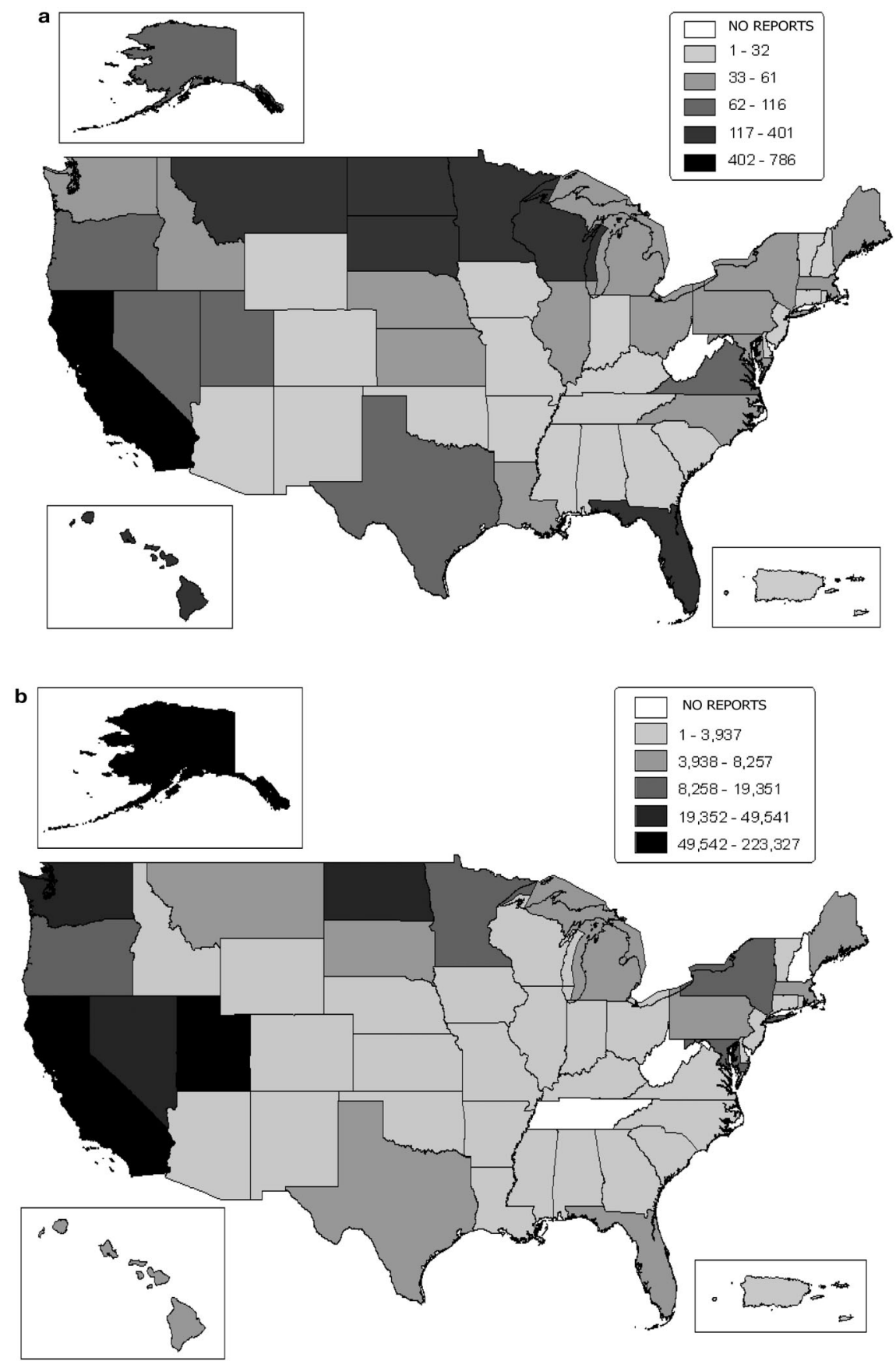

Fig. 1. Number of aquatic bird (a) mortality events and (b) deaths reported in the US (per state) and Puerto Rico between 1971 and 2005. Note: no mortality events were reported from West Virginia; only 2 and 3 mortality events were recorded, respectively,

for Tennessee and New Hampshire, which reported no dead birds from mortality events

Environmental causes were the most important class of mortality events, accounting for 1737 or $48 \%$ of those in the database. Environmental causes were also responsible for the largest proportion of dead birds $(437258$ or $69 \%$ ) in this database (Fig. 2a,b). Over three-quarters of the environmental causes of mortality were due to biotoxin poisoning, representing $78 \%$ of the aquatic bird deaths in this category (Fig. 2c). Of all 344045 deaths due to biotoxins, only 12 were not caused by botulism (Clostridium botulinum) toxin. This supports our categorization of botulism as a noninfectious disease for the purposes of this study, because the majority of individual bird deaths due to C. botulinum are actually due to birds ingesting up the environmentally present toxin, rather than due to primary bacterial infection. 
Table 2. Specific causes of aquatic bird mortality events and aquatic bird deaths based on species habitat use (pelagic/offshore, nearshore/coastal, and freshwater). Note: no totals listed here. A sum of each row for each major category (mortality events or dead aquatic birds) will not equal the respective totals, since many birds utilize $>1$ habitat group, and thus were counted within each

\begin{tabular}{|c|c|c|c|c|c|c|}
\hline \multirow[t]{2}{*}{ Disease category } & \multicolumn{3}{|c|}{$\longrightarrow$ Mortality events } & \multicolumn{3}{|c|}{ Dead aquatic birds } \\
\hline & Pelagic/Offshore & Nearshore/Coastal & Freshwater & Pelagic/Offshore & Nearshore/Coastal & Freshwater \\
\hline \multicolumn{7}{|l|}{ Anthropogenic } \\
\hline Gunshot & $3^{\mathrm{a}}$ & 25 & 24 & 1009 & 1107 & 1099 \\
\hline Net entrapment & 1 & 16 & 14 & $-{ }^{\mathrm{b}}$ & 1467 & 1367 \\
\hline Powerline collision & 0 & 18 & 20 & 0 & 98 & 100 \\
\hline Trauma & 20 & 99 & 90 & 788 & 1426 & 1386 \\
\hline \multicolumn{7}{|l|}{ Environmental } \\
\hline Biotoxin & 9 & 1377 & 1468 & 27 & 139823 & 341376 \\
\hline Natural biology & 1 & 14 & 14 & 8 & 1006 & 1006 \\
\hline Emaciation/Starvation & 63 & 176 & 130 & 79168 & 85195 & 9909 \\
\hline Weather & 1 & 49 & 50 & 1 & 9388 & 9220 \\
\hline \multicolumn{7}{|l|}{ Infectious } \\
\hline Bacterial & 3 & 418 & 419 & 1 & 47987 & 43123 \\
\hline Bacterial or viral & 1 & 5 & 3 & 350 & 3 & 3 \\
\hline Fungal & 9 & 89 & 79 & 334 & 9029 & 8689 \\
\hline Parasites & 4 & 70 & 65 & 12 & 1574 & 1448 \\
\hline Viral & 0 & 113 & 114 & 0 & 66432 & 66434 \\
\hline \multicolumn{7}{|c|}{ Pathology with no etiology } \\
\hline Pathology & 58 & 338 & 315 & 398 & 22175 & 22032 \\
\hline \multicolumn{7}{|l|}{ Toxicosis } \\
\hline Heavy metal & 0 & 30 & 29 & 0 & 115 & 114 \\
\hline Nutritional & 0 & 13 & 13 & 0 & 32 & 32 \\
\hline Oil & 16 & 63 & 54 & 11595 & 13141 & 1571 \\
\hline Pesticide & 0 & 61 & 61 & 0 & 2022 & 2022 \\
\hline Poison & 1 & 24 & 26 & 1 & 574 & 575 \\
\hline Undetermined & 2 & 53 & 54 & 27 & 1766 & 1766 \\
\hline \multicolumn{7}{|l|}{ Undetermined } \\
\hline Open & 27 & 327 & 303 & 11136 & 15521 & 8398 \\
\hline
\end{tabular}

Infectious causes (Fig. 2b) resulted in the second largest category: 1 of 5 of aquatic bird mortalities (125471 or $20 \%$ ). The most commonly diagnosed infectious diseases were viral, representing $54 \%$ of all deaths due to infectious disease (Fig. 2d) and $10.5 \%$ of all aquatic bird deaths. The most commonly diagnosed viral diseases were (duck plague Herpes virus, paramyxovirus of cormorants Paramyxovirus PMV1, and West Nile virus Flavivirus). The most commonly diagnosed bacterial diseases were (avian cholera Pasteurella multocida, chlamydiosis Chalmydia psittici, and salmonellosis Salmonella sp.), representing almost all deaths due to infectious diseases. Fungal and parasitic diseases were found to be relatively minor causes of mortality events ( 7 and $1 \%$, respectively) in the context of both infectious and non-infectious causes of death (Fig. 2d). The most common organisms included: fungal (aspergillosis

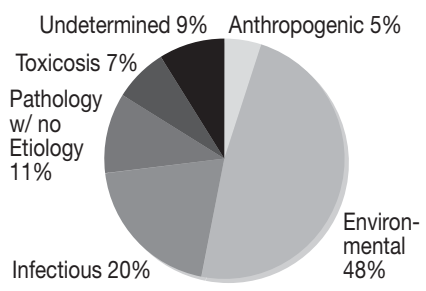

a

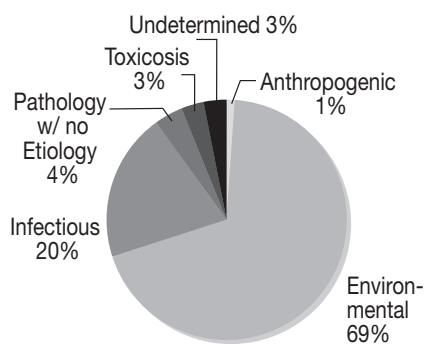

b

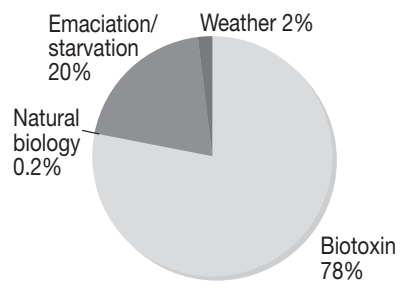

c

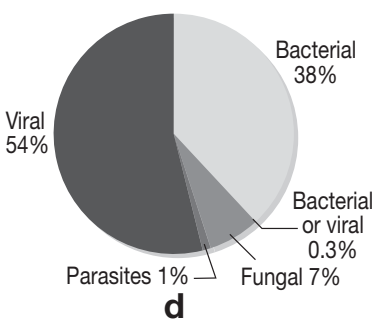

Fig. 2. Specific and general causes of aquatic bird deaths from 1971 to 2005. (a) Cause of death per mortality event shown in percent of 3619 aquatic bird mortality events. (b) Cause of death per bird of 633708 aquatic birds. (c) Specific cause of death per bird of 441045 aquatic bird mortalities due to environmental causes. (d) Specific cause of death per bird of 125471 aquatic bird mortalities due to infectious diseases 
Aspergillus fumigatus) and parasitic diseases (Acanthocephala spp., Eustrongylides spp., Leyogonimus spp., Acanthobdella spp. and Coccidia).

Aquatic bird mortality attributable to anthropogenic interactions accounted for $5 \%$ (180) of the mortality events or $1 \%$ (5580) of the dead birds; toxicosis accounted for $7 \%$ (258) of the mortality events or $3 \%$ (17704) of the dead birds; pathology with no known etiology accounted for $11 \%$ (384) of the mortality events or $4 \%$ (22 544) of the dead birds; and incidents of undetermined origin accounted for $9 \%$ (343) of the mortality events or $3 \%(21064)$ of the dead birds (Fig. 2a,b).

Mortality events of pelagic/offshore species were most frequently linked to environmental events (74; $34 \%$ ) or undiagnosed pathology $(58 ; 26 \%)$. Pelagic seabird deaths (104855) were most commonly associated with environmental causes (79177), and, of these, $99 \%$ was due to emaciation/starvation. Toxicosis accounted for 11623 deaths, of which $99 \%$ was due to petroleum exposure, and undetermined causes represented 11136 individual pelagic bird deaths (Table 2, Fig. 3).

Nearshore/coastal species mortality events were most frequently caused by biotoxin exposure (1377; $41 \%$ ) and bacterial diseases $(418 ; 12 \%)$, while the largest numbers of bird deaths were attributable to biotoxin exposure $(139823 ; 33 \%)$, emaciation/starvation $(85195 ; 20 \%)$, and viral diseases $(66432 ; 16 \%)$ (Fig. 3b,c,e,f).

Mortality events associated with species that use both marine and freshwater habitats were most frequently caused by biotoxin exposure (1468; 44\%) and bacterial diseases $(419 ; 13 \%)$, while the largest numbers of bird deaths were attributable to biotoxin exposure $(341376 ; 65 \%)$, viral diseases $(66434 ; 13 \%)$, and bacterial diseases (43123; 8\%). Other causes of death included pathology of undiagnosed origin (22032 birds; $4 \%$ ), emaciation/starvation $2 \%$ (9909), weather events $2 \%(9220)$, and fungal disease $2 \%$ (8689). Oil exposure was a relatively minor problem $3 \%$ (1571). The most frequently reported diseases for both nearshore/coastal species and those using both marine and freshwater habitats include avian cholera, paramyxovirus, West Nile virus, and salmonellosis.

\section{Temporal and geospatial trends in mortality}

Between 1971 and 1995, the number of mortality events per $5 \mathrm{yr}$ interval increased from $<50$ events to $>700$ events. Environmental, infectious and toxicosis categories were the causes of mortality that increased
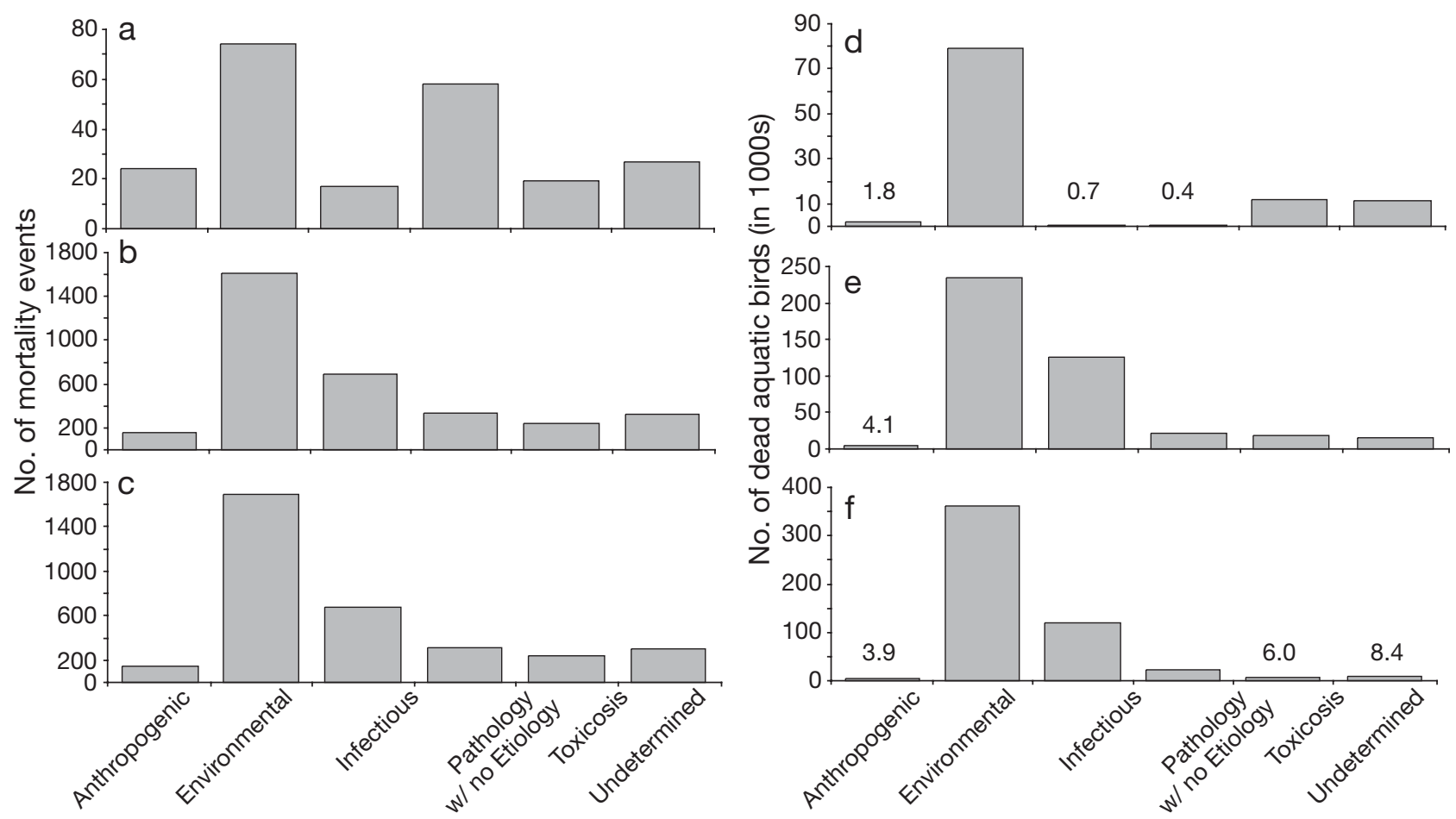

Fig. 3. Bar graphs showing the numbers according to each general category for aquatic bird mortality events $(a, b, c)$, and for numbers of dead aquatic birds (d,e,f). Mortality events for (a) pelagic/offshore bird species, (b) nearshore/coastal bird species, (c) freshwater bird species. Dead aquatic birds (in 1000s) for (d) pelagic/offshore bird species, (e) nearshore/coastal bird species, (f) freshwater bird species 
most prominently among these years (Table 3). From 1995 to 2000, the overall number of mortality events decreased slightly, while the number of events associated with botulism continued to increase and the number of infectious diseases reached a plateau.

Numbers of aquatic birds that died from environmental etiologies increased in magnitude and peaked in 2000 (49 444). Infectious disease related bird deaths peaked in 2005 (11595), after a decline between 1995 and 2000. By 2005, fewer numbers of events were reported to the NWHC overall and the numbers of dead birds from all causes decreased to slightly $<100000$ from the peak numbers of mortalities (257707) reported in 2000 (Table 3).

Finally, we compared the frequency of each category of mortality events occurring in inland versus shoreline states (Table 4) because a high incidence of mortality events was observed in inland states (Fig. 1a). The numbers of mortality events and total dead birds are higher for inland states than for shoreline states. The numbers of biotoxin-associated events and total mortalities for inland states are greater than twice those for shoreline states. There were more than twice as many incidences of mortality events and total dead birds due to bacterial infections and from unknown causes in shore states, while emaciation/starvation was more than 4 times more frequent in shore states compared to inland states and was the cause of almost one-third of aquatic bird deaths.

\section{DISCUSSION}

\section{Causes of mortality}

Our analysis of $30 \mathrm{yr}$ of necropsy data for aquatic birds in the US indicates that environmental factors are the major cause of mortality events and of individual bird deaths. This broad category includes 'emaciation/starvation', which was the leading cause of environmentally related mortalities among pelagic/offshore species. The frequency of mortalities from emaciation/starvation has risen since 1971, demonstrating that it is an important pelagic bird issue from a temporal perspective as well. Other research has suggested that declines in marine fish and marine resources have affected upper level marine predators such as seabirds and killer whales (Piatt \& Anderson 1996, Estes et al. 1998) and that this is correlated with declines in fish catches over the last 3 decades (Piatt et al. 2002). Some authors have linked large-scale seabird wrecks, failed breeding efforts, or a lack of nest initiation among seabirds in North America (from central California, the Pacific Northwest, British Columbia, Alaska, Newfoundland) and Europe (North Sea, Irish Sea, Shetland Islands) over the past 5 to $10 \mathrm{yr}$ to changes in distribution and abundance of prey (Bourne 1976, Sydeman et al. 1994, Piatt \& Anderson 1996, Piatt \& Van Pelt 1997) or anomalous oceanographic conditions (Ainley \& Boekelheide 1990, Bodkin \& Jameson 1991, Daoust et

Table 3. Number, mean, and SE of aquatic bird mortality events and aquatic bird deaths for 5 yr intervals from 1971 to 2005. Data for years preceding 1971 are sparse, so no means and SE were calculated-only the total is given. Of the total numbers 532 mortality events (including 27047 dead birds) had no reporting year, so these are not included in these tables

\begin{tabular}{|c|c|c|c|c|c|c|c|}
\hline $\begin{array}{l}5 \text { yr period } \\
\text { ending in: }\end{array}$ & Anthropogenic & Environmental & Infectious & $\begin{array}{c}\text { Pathology with } \\
\text { no etiology }\end{array}$ & Toxicosis & Undetermined & $\begin{array}{c}\text { Total } \\
\text { number }\end{array}$ \\
\hline \multicolumn{8}{|c|}{ Number of mortality events } \\
\hline Pre-1971 & 2 & 20 & 11 & 0 & 1 & 11 & 45 \\
\hline 1975 & $0.2 \pm 0.2$ & $1.8 \pm 0.8$ & $3.8 \pm 2.5$ & 0 & $1.8 \pm 1.0$ & $0.2 \pm 0.2$ & 39 \\
\hline 1980 & 0 & $17.2 \pm 9.4$ & $6.6 \pm 3.1$ & 0 & $1.6 \pm 1.0$ & $2.4 \pm 0.9$ & 139 \\
\hline 1985 & $0.8 \pm 0.6$ & $36.6 \pm 8.5$ & $11.2 \pm 1.7$ & $2 \pm 1.0$ & $7.2 \pm 2.1$ & $9.2 \pm 1.7$ & 335 \\
\hline 1990 & $5.2 \pm 1.9$ & $53.6 \pm 8.5$ & $16.8 \pm 4.4$ & $4.6 \pm 1.2$ & $18.6 \pm 4.8$ & $12.8 \pm 1.9$ & 558 \\
\hline 1995 & $7 \pm 2.7$ & $78.2 \pm 6.3$ & $30.2 \pm 7.0$ & $6.4 \pm 0.4$ & $9.6 \pm 1.9$ & $20.4 \pm 2.4$ & 759 \\
\hline 2000 & $0.8 \pm 0.2$ & $93.6 \pm 5.6$ & $28.6 \pm 3.5$ & $4 \pm 1.3$ & $4 \pm 1.9$ & $9.8 \pm 1.3$ & 704 \\
\hline \multirow[t]{3}{*}{2005} & $2 \pm 0.3$ & $51.4 \pm 15.6$ & $29.6 \pm 8.1$ & $2.2 \pm 0.9$ & $4.8 \pm 0.6$ & $11.6 \pm 4.6$ & 508 \\
\hline & & & & & & Total & 3087 \\
\hline & \multicolumn{7}{|c|}{ Number of dead birds } \\
\hline Pre-1971 & 4 & 13015 & 4482 & 0 & $0^{\mathrm{a}}$ & 35 & 17536 \\
\hline 1975 & $0^{\mathrm{a}}$ & $828 \pm 501$ & $38 \pm 36$ & 0 & $2 \pm 2$ & $2 \pm 2$ & 4355 \\
\hline 1980 & 0 & $2381 \pm 782$ & $110 \pm 74$ & 0 & $91 \pm 90$ & $23 \pm 8$ & 13027 \\
\hline 1985 & $1 \pm 1$ & $7879 \pm 6179$ & $1043 \pm 753$ & $19 \pm 18$ & $73 \pm 48$ & $1473 \pm 936$ & 52440 \\
\hline 1990 & $360 \pm 213$ & $5051 \pm 1864$ & $1966 \pm 1079$ & $66 \pm 61$ & $2098 \pm 1832$ & $1370 \pm 333$ & 54554 \\
\hline 1995 & $406 \pm 228$ & $13053 \pm 9589$ & $6822 \pm 4165$ & $342 \pm 179$ & $1181 \pm 800$ & $816 \pm 333$ & 113101 \\
\hline 2000 & $190 \pm 190$ & $49444 \pm 41166$ & $1764 \pm 506$ & $18 \pm 12$ & $13 \pm 4$ & $112 \pm 83$ & 257707 \\
\hline \multirow[t]{2}{*}{2005} & $57 \pm 38$ & $6526 \pm 3349$ & $11595 \pm 4967$ & $120 \pm 109$ & $80 \pm 42$ & $409 \pm 306$ & 93941 \\
\hline & & & & & & Total & 606661 \\
\hline
\end{tabular}


Table 4. Comparison of specific causes of aquatic bird mortality events and aquatic bird deaths between inland and shoreline states

\begin{tabular}{|lrrrr|}
\hline \multirow{2}{*}{$\begin{array}{l}\text { Causes of } \\
\text { mortality }\end{array}$} & \multicolumn{4}{c}{ Percent of specific causes of: } \\
& $\begin{array}{c}\text { Mortality events } \\
\text { Inland }\end{array}$ & Shore & Dead birds \\
Inland & Shore \\
\hline Bacterial & 5.6 & 14.9 & 4.4 & 11.0 \\
Bacterial or viral & 0.2 & 0.2 & 0.0 & 0.1 \\
Biotoxin & 66.7 & 28.9 & 81.3 & 24.9 \\
Fungal & 0.4 & 3.5 & 1.6 & 1.3 \\
Gunshot & 0.9 & 0.7 & 0.0 & 0.7 \\
Heavy metal & 0.4 & 1.0 & 0.0 & 0.0 \\
Natural biology & 0.1 & 0.6 & 0.0 & 0.3 \\
Net entrapment & 0.0 & 0.6 & 0.0 & 0.5 \\
Nutritional & 0.5 & 0.3 & 0.0 & 0.0 \\
Oil & 0.2 & 2.8 & 0.0 & 4.3 \\
Open & 5.3 & 11.4 & 0.4 & 6.5 \\
Parasites & 1.5 & 2.2 & 0.2 & 0.3 \\
Pathology & 6.2 & 12.6 & 5.1 & 1.9 \\
Pesticide & 0.4 & 2.3 & 0.0 & 0.6 \\
Poison & 0.6 & 0.8 & 0.0 & 0.2 \\
Powerline collision & 0.5 & 0.6 & 0.0 & 0.0 \\
Emaciation/Starvation & 1.6 & 7.2 & 0.6 & 28.3 \\
Trauma & 1.7 & 3.9 & 0.1 & 0.6 \\
Undetermined & 0.4 & 2.1 & 0.3 & 0.3 \\
Viral & 5.3 & 2.2 & 5.0 & 16.3 \\
Weather & 1.8 & 1.3 & 1.1 & 1.9 \\
\hline
\end{tabular}

al. 1998). Our data suggest that this cause of death has increased in importance, although it is not possible to confirm whether the starvation was primarily due to a lack of prey related to overfishing or climate issues, or another cause that was not evident upon necropsy.

The leading cause of environmentally related mortalities and events among nearshore/coastal and freshwater bird species was biotoxin exposure and, specifically, botulinum intoxication (Types $\mathrm{C}$ and $\mathrm{E}$ ) or an untyped botulism (most likely Type $\mathrm{C}$ or E). However, it is important to note that our inclusion of botulism as an environmental, rather than infectious, cause of death is critical to distinguishing which general cause of death is the most important (if botulism is considered infectious, the dominant cause of overall mortality in our database would be infectious diseases). While it is true that infection with Clostridium botulinum is an infectious disease, this is rarely the cause of death in wild waterbirds; rather, the ingestion of environmental botulinum toxin (produced either directly in the gastrointestinal tract of infected birds, or from environmental multiplication of $C$. botulinum) is the most common cause of death. Importantly, the environmental causes of death most commonly reported in scientific publications and non-scientific media (chemical pollution) are less significant in our database than either botulinum intoxication or infectious diseases.

Our analysis confirms that infectious diseases are an important cause of mortality events and individual bird deaths (in the 1000s per annum) in the US alone, especially among nearshore/coastal and freshwater aquatic birds. Mass mortality events were caused more often by bacterial events than by viral events; however, the number of dead aquatic birds is greater due to viral etiologies. Previous authors have suggested that bacterial diseases are a significant burden on aquatic bird populations (Reece 1989); however, our data do not demonstrate this. Population-scale effects of microbial and parasitic infections in aquatic birds are poorly understood (Reece 1989, Muzzafar \& Jones 2004), and, although bacterial pathogens are often documented in aquatic birds, it is often unclear whether they have played a role in mortality events or in beach-cast birds. The recognition of the West Nile virus as a cause of death in aquatic birds is interesting. This introduced pathogen is responsible for high mortality rates in a number of terrestrial species, and its impact on aquatic birds adds another dimension to the toll of introduced pathogens on North American ecosystems.

A suite of other anthropogenic environmental factors have caused aquatic bird mortality, including marine pollution in the form of oil spills, pesticides, heavy metals, trauma, gunshot, collisions with power lines, and fishing net or fishing line entanglement. Although 1000 s of pelagic birds have been impacted by net entrapment over the past $30 \mathrm{yr}$, these mortalities were not part of this database and should be considered as an additional significant impact to aquatic birds, although not represented here. A more complete assessment of pelagic bird mortalities would include this data as well. Finally, we did not find algal blooms to be a frequent cause of mortality in the current database, but recent advances in diagnostic techniques that detect the presence of algal toxins may explain why others have more recently reported aquatic bird mortality due to algal blooms (Williams et al. 1992, Sherman 2001, Sherman \& Epstein 2001).

\section{Temporal trends in mortality}

A number of temporal trends can be gleaned from our datasets. First, there was a striking increase in the number of birds submitted for diagnostic evaluation from 1971 through 2000, followed by a decrease during the last $5 \mathrm{yr}$ of the study. The rise in reports likely reflects increases in (1) interest in aquatic bird conservation, (2) human inhabitants and human visitation to coastal locations, (3) funding for monitoring and studies of this type from federal, state, and private sources, (4) interest in the impact of oil pollution on aquatic birds, as well as (5) the expansion of diagnostic facilities such as the NWHC. It is unclear why the number of reports declined from 2000 to 2005, but changing 
weather patterns resulting in drought, changes in population numbers, or changes in the use of traditional wintering and stop-over areas could have resulted in a change in the disease outbreak patterns observed.

While the overall temporal trend in number of birds submitted for diagnostic evaluation may be biased by changes in sampling effort and funding, comparison of temporal trends among causes of death are less biased due to the standardized necropsy and diagnostic methods used throughout the duration of this study. Thus, the increasing importance of infectious diseases and environmental causes of mortality events and bird deaths from 1971 to 2000 is likely a real trend, reflecting some underlying, but unknown, cause. Viral disease events were relatively unimportant until the mid1990s, when West Nile virus emerged in the US. The only aquatic species reported to have West Nile virus as a major cause of mortality is the American white pelican Pelecanus erythrorhynchos. Individual mortalities were reported in many aquatic bird species, including double-crested cormorant Phalacrocorax auritus, great egret Ardea alba, great blue heron A. herodias, black-crowned night heron Nycticorax nycticorax, ring-billed gull Larus delawarensis, California gull $L$. californicus, Franklin's gull L. pipixcan, and American avocet Recurvirostra americana. Viral diseases also play an increasingly important role in the health of aquatic birds, as has been suggested in other studies (Daoust et al. 1998, Sherman 2001, Sherman \& Epstein 2001, Harvell et al. 1999, Converse \& Kidd 2001, Friend et al. 2001).

\section{Limitations to the database}

While we can establish some very important trends from this database on aquatic bird mortalities, it is important to recognize certain limitations as well. The counts of dead birds that comprise the aquatic bird database may be inherently biased because only dead birds encountered by humans in the environment, and subsequently submitted for diagnosis, became data points. Therefore, a counting bias exists towards birds submitted for analysis from geographic locations where (1) public access exists; (2) human population densities are large enough to provide some level of 'indirect' surveillance for dead birds; (3) birds are large enough to be seen by people passing by; (4) locations are monitored regularly by natural resource agency personnel as in the case of Wildlife Refuges and National Parks; (5) predators (wild or domestic animals) do not remove all carcasses before they are recovered; (6) formalized beached-bird surveys are conducted on a regular basis; and (7) ecological conditions warrant increased surveillance (beach closures, algal blooms, oil spill events). We observed a discrepancy in the number of birds represented in the database based on preferred ecological habitats. Numbers of birds in the database that use both marine and freshwater habitats (521670) and coastal marine habitats (419881) outnumbered birds from pelagic marine habitats (104 855), demonstrating that some bias exists based on natural history. Finally, there were considerable changes in sampling effort over the period of the present study, which likely affect the rigor of analyses of temporal trends in overall mortality.

These biases suggest that the number of mortality events and especially the number of individual birds found dead greatly under-represent the true magnitude of aquatic bird mortality in the US. It has been demonstrated for common murres Uria aalge collected during oil spills and from carcass-persistence studies that only a small proportion ( $<10$ to $15 \%)$ of birds that are oiled or are part of 'carcass drift studies' wash ashore (Ford et al. 1987, Piatt \& Ford 1996, Ford et al. 2004). Consequently, fewer birds are actually recovered by personnel monitoring beaches. Most dead birds either sink at sea or, once deposited on the beach, are scavenged by wildlife or domestic animals, washed back out to sea and missed by observers monitoring the coastline, or washed ashore on coastlines that are inaccessible or not monitored by people (Piatt \& Van Pelt 1997, Carter 2003, Hampton \& Zafonte 2007).

\section{CONCLUSIONS}

Our analysis provides an important first attempt to use data from diagnostic evaluations and necropsies to understand broad trends in aquatic mortality in the US. The results suggest that environmental causes (including the biotoxin produced by Clostridium botulinum) are the most important cause of death and that infectious diseases are also significant in overall mortality. By applying a conservative correction for the underreporting bias (only 10 to $15 \%$ of aquatic birds that die are recovered, based on carcass-recovery studies), we believe that the final numbers of birds impacted by botulinum toxin and infectious diseases may have been at least 4 million over the study period and that aquatic bird mortality from all sources may have been $>6$ million birds. Considering the possibility that recovery rates for carcasses are closer to $5 \%$ than the assumed 10 to $15 \%$ and that large numbers of aquatic birds aggregate in certain coastal ecosystems at certain times of year, these numbers could be an order of magnitude higher. Other authors have suggested that infectious diseases are responsible for significant effects on marine bird populations (Friend et al. 2001); 
our database does not permit statistical testing of this hypothesis but demonstrates that very large amount of aquatic bird mortalities are attributable to infectious diseases. Most importantly, our analyses highlight the value of long-term collection of mortality data, even where biases exist, in order to better understand the threats to aquatic birds, wildlife conservation, and ecosystem health. To increase knowledge of population level impacts of diseases in our changing marine ecosystem, wildlife disease surveillance efforts from multiple sources will need to be combined and analyzed. For example, national wildlife disease surveillance programs, beached-bird monitoring programs, rehabilitation center data, and aquatic bird monitoring programs all provide information about morbidity and mortality, breeding effort, breeding success, and changes in population sizes. Combining these data will allow a more thorough evaluation of impacts to aquatic bird species and provide a potentially robust early warning system for larger scale marine perturbations. This has serious implications for aquatic bird health, but also for human health, as we use aquatic birds as sentinels for contamination of the marine ecosystems that people depend on for food, recreation, and their well being.

Acknowledgements. We are grateful to the many volunteers and professionals who supplied carcasses and samples to the USGS National Wildlife Health Center (USGS-NWHC) and to the many people that contributed to the necropsies, sample handling and preparation, diagnostics, and database management. In particular, we appreciate the efforts of S. Wright, K. Cunningham, and C. Acker of the USGS-NWHC, who retrieved and provided us with the data used in this study. We also thank USGS-NWHC staff M. Friend, D. Blehert, and T. Rocke for their reviews of this manuscript that have resulted in significant improvements. This study was funded in part by NIAID Contract NO1-AI-25490, NSF Grant EF-0622391, and core funding to the Consortium for Conservation Medicine from the V. Kann Rasmussen Foundation. Any use of trade, product, or firm names is for descriptive purposes only and does not imply endorsement by the US government.

\section{LITERATURE CITED}

Ainley DG, Boekelheide RJ (1990) Seabirds of the Farallon Islands. Stanford University Press, Stanford, CA

Berger L, Speare R, Daszak P, Green DE and others (1998) Chytridiomycosis causes amphibian mortality associated with population declines in the rainforests of Australia and Central America. Proc Natl Acad Sci 95:9031-9036

Bodkin JL, Jameson RJ (1991) Patterns of seabird and marine mammal carcass deposition along the central California coast, 1980-1986. Can J Zool 69:1149-1155

Bourne WRP (1976) The mass mortality of common murres and guillemots in the Irish Sea in 1969. J Wildl Manage 40:789-792

Burger J, Gochfeld M (2004) Marine birds as sentinels of environmental pollution. Ecohealth 1(3):263-274

Camphuysen CJ, Heubeck M (2001) Marine oil pollution and beached bird surveys: the development of a sensitive monitoring instrument. Environ Pollut 112:443-461

Carter HR (2003) Oil and California's seabirds: an overview. Mar Ornithol 31:1-7

Converse KA, Kidd GA (2001) Duck plague epizootics in the United States, 1967-1995. J Wildl Dis 37:347-357

Daoust PY, Conboy G, McBurney S, Burgess N (1998) Interactive mortality factors in common loons from Maritime Canada. J Wildl Dis 34:524-531

Daszak P, Cunningham AA (1999) Extinction by infection. Trends Ecol Evolut 14:279

Daszak P, Cunningham AA, Hyatt AD (2001) Anthropogenic environmental change and the emergence of infectious diseases in wildlife. Acta Trop 78(2):103-116

Dobson A, Foufopoulos J (2001) Emerging infectious pathogens of wildlife. Philos Trans R Soc Lond B 356(1411): 1001-1012

Domingo M, Ferrer L, Pumarola M, Marco A, Plana J, Kennedy S, McAliskey M, Rima BK (1990) Morbillivirus in dolphins. Nature 348:21

Estes JA, Tinker MT, Williams TM, Doak DF (1998) Killer whale predation on sea otters linking oceanic and nearshore ecosystems. Science 282(5388): 473-476

Ford RG, Page GW, Carter HR (1987) Estimating mortality of seabirds from oil spills. In: Proc 1987 Oil Spill Conference. American Petroleum Institute, Washington, DC, p $547-551$

Ford RG, Himes Boor GK, Reed NA (2004) Background oiling rate and historic beached bird deposition rate study. Final report to the US Fish and Wildife Service, Oregon Fish and Wildlife Office, Corvallis, OR

Friend M, McLean RG, Dein FJ (2001) Disease emergence in birds: challenges for the twenty-first century. Auk 118: 290-303

Hampton S, Zafonte M (2007) Exploring factors influencing beached bird collection during the Luckenback 20012002 oil spill. Mar Ornithol 34:109-113

Harvell CD, Kim K, Burkholder JM, Colwell RR and others (1999) Emerging marine diseases-climate links and anthropogenic factors. Science 285(5433):1505-1510

Harvell CD, Mitchell CE, Ward JR, Altizer S, Dobson AP, Ostfeld RS, Samuel MD (2002) Climate warming and disease risks for terrestrial and marine biota. Science 296: 2158-2162

Lederberg J, Shope RE, Oakes SCJ (1992) Emerging infections: microbial threats to health in the United States. Institute of Medicine, National Academy Press, Washington, DC

Lyles AM, Dobson AP (1993) Infectious-disease and intensive management-population-dynamics, threatened hosts, and their parasites. J Zoo Wildl Med 24:315-326

Muzzafar SB, Jones IL (2004) Parasites and diseases of auks (Alcidae) of the world and their ecology - a review. Mar Ornithol 32: 121-146

Newman SH, Ziccardi MH, Berkner AB, Holcomb J, Clumpner C, Mazet JKA (2003) A historical perspective on oil spill response in California. Mar Ornithol 31:59-64

Newman SH, Harris RJ, Tseng FS (2006) Beach surveys past, present, and future: Toward a global surveillance network for stranded seabirds. Mar Ornithol 34: 87-90

Piatt JF, Anderson P (1996) Response of common murres to the Exxon Valdez oil spill and long-term changes in the Gulf of Alaska marine ecosystem. In: Rice SD, Spies RB, Wolfe DA, Wright BA (eds) Proc Exxon Valdez Oil Spill Symp. Am Fish Soc Symp 18:720-737

Piatt JF, Ford RG (1996) How many seabirds were killed by the Exxon Valdez oil spill? In: Rice SD, Spies RB, Wolfe 
DA, Wright BA (eds) Proc Exxon Valdez Oil Spill Symp. Am Fish Soc Symp 18:712-719

Piatt JF, Van Pelt TI (1997) Mass-mortality of guillemots (Uria aalge) in the Gulf of Alaska in 1993. Mar Pollut Bull 34(8):656-662

Piatt JF, Litzow MA, Prichard AK, Roby DD (2002) Response of pigeon guillemots to variable abundance of high-lipid and low-lipid prey. Oecologia 132: 286-295

Reece RL (1989) Avian pathogens: their biology and methods of spread. In: Cooper JE (ed) Diseases and threatened birds. Technical Publication No. 10, International Council for Bird Preservation, Cambridge, p 1-23

Rocke TE, Friend M (1999) Botulism. In: Friend M, Franson JC (eds) Field manual of wildlife diseases-general field procedures and diseases of birds. Information and Technology Report 1999-2001, US Dept. of the Interior, US Geological Survey, Washington, DC, p 271-281

Schrag SJ, Wiener P (1995) Emerging infectious disease: What are the relative roles of ecology and evolution? Trends Ecol Evolut 10(8):319-324

Sherman BH, Epstein PR (2001) Past anomalies as a diagnostic tool for evaluating multiple marine ecological disturbances:

Editorial responsibility: Howard Browman (Associate Editorin-Chief), Storebø, Norway applying the North American prototype to the Baltic Sea ecosystem. Human Ecol Risk Asses (7(5): 1519-1510

Smolinski MS, Hamburg MA, Lederberg J (2003) Microbial threats to health: emergence, detection, and response. The National Academies Press, Washington, DC

Stone R (2000) Canine virus blamed in Caspian seal deaths. Science 289:2017-2018

Sydeman WJ, McLaren EB, Pyle P (1994) ENSO 1992 and ENSO 1993: biological consequences and seabird population regulation in the California Current. Pac Seabirds 21:50

Warner RE (1968) The role of introduced disease in the extinction of the endemic Hawaiian avifauna. Condor 70: $101-120$

Williams EH Jr, Bunkley-Williams L, Lopez-Irizarry I (1992) Die-off of brown pelicans in Puerto Rico and the United States Virgin Islands. Am Birds 46(5):1106-1108

Williams EH Jr, Bunkley-Williams L, Peters EC, PintoRodriguez B and others (1994) An epizootic of cutaneous fibropapillomas in green turtles (Chelonia mydas) of the Caribbean: Part of a panzootic? J Aquat Anim Health 6: $70-78$

Submitted: September 28, 2006; Accepted: October 26, 2007 Proofs received from author(s): November 21, 2007 